\title{
Understanding the Use of Timber in Semi-Arid Regions: Kurdistan Region of Iraq, a Case Study
}

\author{
Mohanad Yaseen Abdulwahid ${ }^{1}$ (D), Isaac Galobardes ${ }^{2, *(D)}$ and Hassan Radoine ${ }^{2}$ \\ 1 Department of Civil Engineering, Faculty of Engineering, Koya University, \\ Koya KOY45, Kurdistan Region-F.R., Iraq; mohanad.yaseen@koyauniversity.org \\ 2 School of Architecture, Planning \& Design, Mohammed VI Polytechnic University, \\ Ben Guerir 43150, Morocco; hassan.radoine@um6p.ma \\ * Correspondence: isaac.galobardes@um6p.ma
}

check for updates

Citation: Abdulwahid, M.Y.;

Galobardes, I.; Radoine, H.

Understanding the Use of Timber in Semi-Arid Regions: Kurdistan Region of Iraq, a Case Study. Sustainability 2021, 13, 11845. https://doi.org/ $10.3390 /$ su132111845

Academic Editor: Asterios Bakolas

Received: 6 August 2021

Accepted: 19 September 2021

Published: 27 October 2021

Publisher's Note: MDPI stays neutral with regard to jurisdictional claims in published maps and institutional affiliations.

Copyright: (c) 2021 by the authors. Licensee MDPI, Basel, Switzerland. This article is an open access article distributed under the terms and conditions of the Creative Commons Attribution (CC BY) license (https:// creativecommons.org/licenses/by/ $4.0 /)$.

\begin{abstract}
The use of timber in the building industry has expanded in many countries over the last 20 years due mainly to its light weight, low adverse impact to the environment, and fair mechanical properties. Despite the development of the construction industry in the Kurdistan Region in Iraq (KRI) in recent years, timber product utilization is still very limited. Therefore, the purpose of this study was to investigate the feasibility of further utilizing timber-based products in the building industry in semi-arid regions using the KRI as a case study. A review of timber product utilization in the region was conducted first and the general properties of timber products were followed. Based on this, a survey focusing on the current situation and suitability of localized grown timber products was carried out to study the feasibility. This article concludes that the use of timber-based products in the KRI presents different barriers, with the availability in the market and technicality of construction with the material being the strongest ones. The article recommends that it is imperative to further research how to promote timber's utilization in the KRI to be in line with sustainable development.
\end{abstract}

Keywords: timber; sustainability; AEC industry; Kurdistan Region of Iraq; semi-arid region

\section{Introduction}

The 2030 Agenda for Sustainable Development defined the Sustainable Development Goals to tackle climate change. Besides, all greenhouse gas (GHG) emissions from the built environment need to be eliminated by 2040 to meet Paris Climate Agreement targets. Since the construction industry is responsible of $40 \%$ of global GHG emissions, achieving these goals and targets results in an immense challenge, making this sector one of the major players that must lead the changes in our society to attain sustainable development [1].

Studies show that $11 \%$ of the total emissions produced by this industry are due to building materials [1]. From this, $70 \%$ is due to the production of concrete. Over the past century, this material has become the highest-volume manufactured product on Earth [2]. In fact, more than $4 \mathrm{Gt}$ of cement, a key ingredient for concrete, was produced globally in 2019, with being China the largest producer, accounting for 55\% of global production [3]. Considering the Kurdistan Region of Iraq (KRI), six cement factories produce about 38,630 tons of cement each day, which is equivalent to $14 \mathrm{Mt}$ per year, approximately [4]. These numbers do not represent a big global amount; however, in many other developing countries and/or regions, concrete is the main construction material used for new construction [5]. This occurs mainly due to concrete's versatility, highly reliable performance, and availability and low cost of its raw materials and processing technology. Nevertheless, other indicators need to be considered if sustainable development is to be achieved locally and globally. In that regard, an extra 2.5 billion people are expected to be on our planet by 2050, leading to a higher demand for new buildings. This demand estimates 130 billion $\mathrm{m}^{2}$ of additional housing, leading to an enormous material need [6]. Therefore, choosing traditional materials such as concrete would produce a huge pressure 
on the environment, jeopardizing our future generations. It is now, therefore, that new solutions must be explored to find more suitable materials for future construction.

Timber products may be a solution. Timber has been a popular building material since time immemorial and, even though the use of it might be related to global deforestation, timber cannot be questioned as being one of the most sustainable construction materials due its diverse advantages [7]. Firstly, it is a natural renewable resource; in that sense, a tree can be grown to a suitable harvest size in 25 to 80 years (depending on the species), whereas conventional construction materials are only renewed over geological time [8]. Secondly, through photosynthesis, trees absorb carbon. This carbon is fixed in wood and when trees are harvested, their carbon is stored in timber (around a ton of carbon is stored in every cubic meter of timber [8]). Then, following sustainable forestry practices [9] and replacing harvested trees with new ones, the beneficial net effect is removing carbon from the atmosphere. Related to that, timber has the lowest embodied energy compared to conventional building materials [7]. In that sense, Lippke et al. [10] found that steel and concrete emit $26 \%$ to $31 \%$ more greenhouse gas emissions than wood. A report from Yale University stated that using more wood and less conventional construction materials (steel and concrete) in the construction industry would significantly reduce global $\mathrm{CO}_{2}$ emissions and fossil fuel use [11]. Besides, Yue et al. [12] mentioned that the energy consumption of timber structures is $65 \%$ of that of brick-concrete structures, and the $\mathrm{CO}_{2}$ emission of timber structures is only $70 \%$ of that of brick-concrete structures. Finally, the high durability, low maintenance, higher construction speed, beautiful aesthetics, good insulation, and non-toxicity are other examples of the goodness of this construction material $[8,13]$.

In that positive context, several studies based on surveys were done in different countries/regions to understand how to further use timber and engineer timber. Gold and Rubik [14] found that timber as a construction material has a positive association with well-being, aesthetics, and eco-friendliness. However, the study showed prejudice in the minds of consumers in terms of fire resistance, durability, and stability. On the other hand, $X i a$ et al. [15] reported that the most significant barriers to using timber in construction are maintenance costs and fire risk, together with a limited awareness of the emerging timber technologies available. The results of Caniato et al. [16] indicated positiveness for acoustic and thermal insulation of the material but showed similar drawbacks.

Based on these results, timber construction does present certain challenges, such as higher maintenance compared to other materials and biological attacks like mold and fungi attacks. Nevertheless, the two biggest issues to be minimized to see timber as good technically compared to our conventional materials are related to fire safety and stiffness. Besides, on a local scale, there is a low availability of this product in the KRI. The lack of wood in semi-arid countries such as Iraq is seen as an impediment to using timber as a primary construction material, leading to other issues that need to be confronted [17-19]. Despite these drawbacks, studies show that young people, and therefore the future of our societies, regard timber construction positively in comparison to other construction methods, based on aesthetic appeal and ecological advantages [20].

Hence, this research aims to understand the use of timber in the semi-arid regions in the world (e.g., North Africa), using the KRI as an example of study. Analyzing the results of a survey performed, the authors show the current situation of timber construction in the region, spotting the main problems faced by the industry to increase the use of this sustainable construction material. Besides, the authors propose actions to be considered to make suitable a wider utilization of timber in semi-arid regions to achieve sustainability goals based on international approaches.

\section{Utilization of Timber in KRI}

The geo-cultural territory of Kurdistan generally comprises the following four areas: southeastern Turkey (Northern Kurdistan), northern Iraq (Southern Kurdistan), northwestern Iran (Eastern Kurdistan), and northern Syria (Western Kurdistan). The Southern Kurdistan or Kurdistan Region of Iraq (KRI) is one of the most prosperous regions in the 
Middle East because of its petroleum and mineral resources [21]. Currently, the KRI is witnessing great urban development at the building and urban levels. It covers an area of approximately $40,000 \mathrm{~km}^{2}$. The total population in 2014 was estimated to be 7.2 million, of which more than $75 \%$ are estimated to live in urban areas [22]. The climate in the KRI is defined as semi-arid continental with cold, snowy winters and hot, dry summers.

The KRI gathers most of Iraq's natural woodlands in the Highlands. The Highlands are a series of mountains that go from the bordering east (Iran) to the north (Turkey). According to an estimation [23], green spaces presently account for only $12.44 \%$ of KRI total land area. Oak forests make up approximately $90 \%$ of the total forest cover in the region, and the remaining $10 \%$ comprises plantation, pine forest, riverine, and others (e.g., Pistacia khinjuk, Crataegus azaro), often mixed with the oak forests [24]. It is important to remark that oaks are a large group of hardwood trees that can be used industrially to produce timber, furniture leathering, and veneer production [25]. Are et al. (2021) studied physical and mechanical properties of oak trees found in the KRI [25]. The results showed that its density and specific gravity are classified as heavy, hard, dense, and strong wood that may be used in different industries, including construction.

Even though the forest sector of the KRI is little developed, successive wars and droughts have caused severe damage to natural ecosystems [26]. Unless extensive forest plantations are adopted and developed in medium and high mountain locations, investments in the field of wood products are currently doubtful. Since historically, KRI forests had little economic value from the wood products industry [27], most of the requirements, particularly in construction, are not fulfilled, leading to importing the timber needed. In that sense, the local wood productivity is just limited to the furniture industry and heating [26-28]. Furthermore, in the last decade, 1.3 million acres of forest have been destroyed. Fires have been the main reason for the retrogression of forest vegetation. The biggest number of fires occurred recently, leading to a loss of $57 \%$ of forestland. Besides, in recent years, the financial crisis and the war on the Islamic State of Iraq and Syria (ISIS) have taken their toll on forests [23].

In this context, timber construction faces difficult challenges in the KRI. However, timber has been used in the region for the construction of buildings since ancient times. The use of wood in the manufacture of ceilings and columns in the old buildings found in the Erbil Citadel is clear evidence that the use of wood in construction started long ago (Figure 1) [29]. At that time, people already perceived timber as a good construction material with many advantages [30,31]. In the last 10 years, timber has become a building material used just for decoration and thermal and acoustic insulation. There is no information in the literature about the uses of engineered timber products in the KRI.

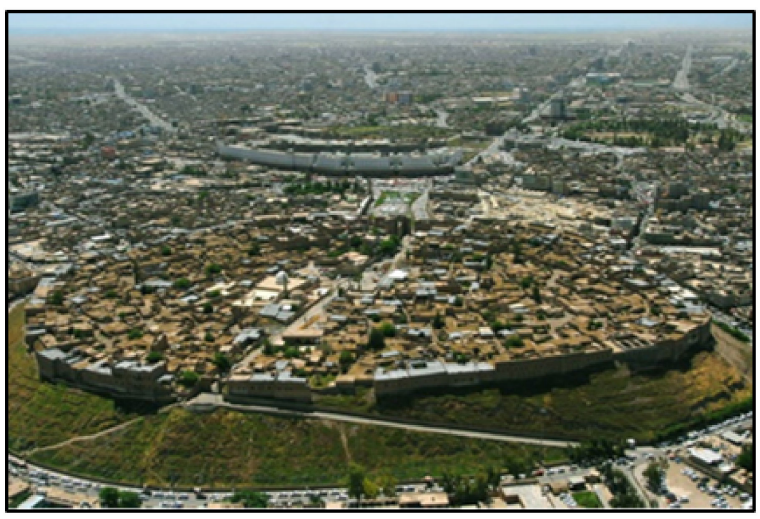

(a)

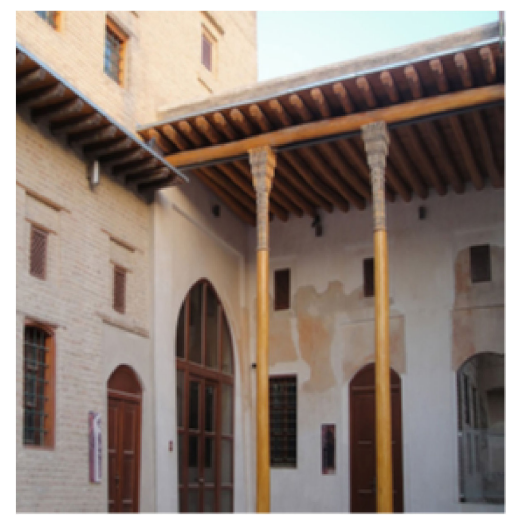

(b)

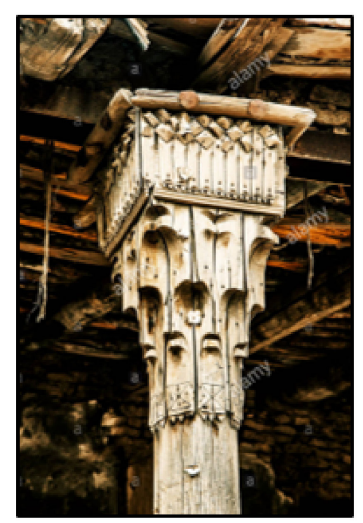

(c)

Figure 1. Erbil citadel in KRI: (a) timber column and ceilings in a house in the citadel, and (b) a detail of a timber column (c). 


\section{Research Methodology}

In this study, a survey, which is the most frequent technique for investigating people's thoughts [32], was designed to analyze the current situation and context of the timber used in the Kurdistan Region of Iraq (KRI). Questions were prepared to understand how the architecture, engineering, and construction (AEC) industry perceives timber over other conventional construction materials, to comprehend how familiar the industry is with the use of timber and how it is currently used, and to see what the main barriers are regarding the further use of timber in the region. These questions were gathered in six main groups to collect information about:

(1) Company/Organization: These questions focused on knowing the area of influence of the company/organization and field and type of business.

(2) Construction Materials: Firstly, surveyees classified the importance of given characteristics of materials when selecting a construction material. Then, the same characteristics were used to rank different construction materials (timber, steel, concrete, masonry, and earth) based on their performance.

(3) Timber Construction: These questions focused on the familiarity with timber construction in general and the actual current use of timber in surveyees' projects.

(4) Potential of Timber Construction in the KRI: These questions were about the likeliness of using timber in future projects considering the current international sustainability agreements.

(5) Limitations of Timber Construction in the KRI: Three different barriers were selected from a list of seven given choices.

(6) Novel Wood-Based Products: Surveyees were asked about their familiarization with different engineered wood products.

All questions were assembled in a questionnaire, which is considered easier to use, faster to complete, clearer, and more widely recognized in the field of construction and engineering management. The questionnaire was sent by email to architecture/engineering design studios, construction companies, universities, and manufacturers in the KRI in an e-format. A total of 160 surveyees participated in this study and all data were considered for analysis. Figure 2 displays the percentages of respondents considering the field and type of business. Notice that $55.80 \%$ businesses act only in the KRI, whereas $38.30 \%$ and $5.90 \%$ work nationally (Iraq) and internationally, respectively.

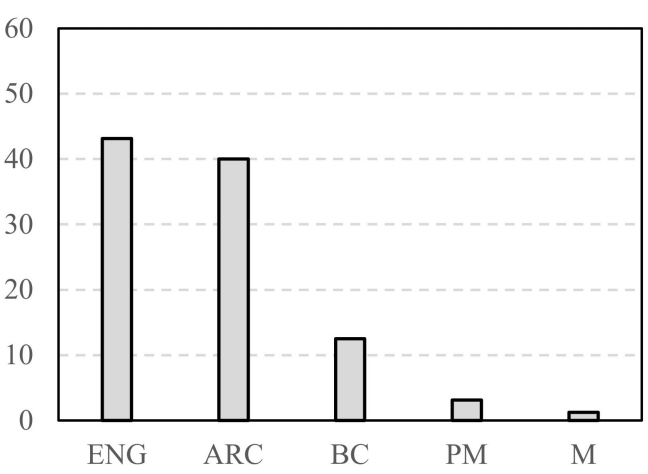

(a)

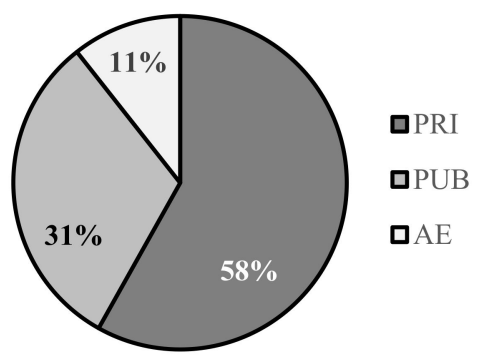

(b)

Figure 2. Respondents' business nature: field (ENG: engineers; ARC: architects; BC: building/contracting; PM: project managers; M: manufacturers) (a) and type (PRI: private company; PUB: public company; AE: academic and education) (b) of business (units: \%).

\section{Results and Analysis}

It was important to learn what the main characteristics are that the respondent consider essential during the selection of a construction material in order to make proposals. Hence, the survey presented a list of nine characteristics that the surveyees needed to classify from the least to the most important one. The characteristics were fire performance, 
environmental friendliness, durability, cost of production, cost of material, cost of maintenance, availability in the market, aesthetics, and acoustic performance. Giving weights to the answers (9 points to 1 point for most to least important, respectively) and considering the percentages of responses received, the characteristics were classified. Table 1 presents the characteristics with their final punctuation.

Table 1. Essential characteristics for material selection.

\begin{tabular}{cc}
\hline Characteristic & Punctuation \\
\hline Fire performance & 6.08 \\
Environmental friendliness & 6.39 \\
Durability & 6.47 \\
Cost of production & 6.38 \\
Cost of material & 6.37 \\
Cost of maintenance & 6.29 \\
Availability in the market & 6.59 \\
Aesthetics & 6.25 \\
Acoustic performance & 6.10 \\
\hline
\end{tabular}

The results show how the most important characteristic was the availability in the market, whereas the least was fire protection. The AEC industry in the KRI also considered the durability of the materials to be important, as well as whether they are environmentally friendly. On the other hand, the characteristics of acoustic performance and aesthetics were not considered essential.

Then, respondents were asked to choose the construction material, considering timber, steel, concrete, masonry, and earth, that presents the best performance for each one of the characteristics. Figure 3 gathers the results obtained in the survey in a staked bar chart. Aesthetics, cost of material, durability, cost of production, and environmental friendliness were the best characteristics chosen for timber, steel, concrete, masonry, and earth, respectively.

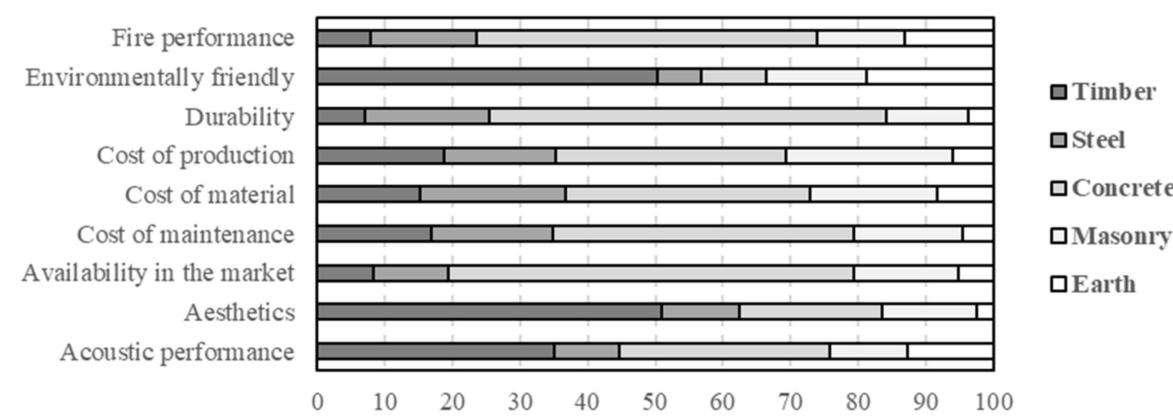

Figure 3. Characteristics of different construction materials (units: \%).

Considering the average of the percentages obtained as an indicator, concrete $(38.38 \%)$ was the most chosen construction material, considering all characteristics listed, followed by timber $(23.35 \%)$. The lowest percentage was obtained by earth $(8.31 \%)$. These results demonstrate why concrete is the most used and appealing construction material nowadays and the new interesting sustainable trend that using timber can offer. It is important to remark that durability $(7.01 \%)$, fire performance $(7.84 \%)$, and availability in the market $(8.39 \%)$ were the worst characteristics presented by timber. Notice that the last, availability in the market, was the most important characteristic the AEC industry in the KRI considered when choosing a construction material. This fact has been observed in other countries such as Australia, Iran, and South Africa [33-35].

On the other hand, surveyees were asked about how familiar they were with timber construction. As Figure 4a shows, none of the respondents were unfamiliar with timber. However, only $16.88 \%$ of them were very familiar with timber construction. Notice that 
being familiar was described as the ability to design either structural or non-structural elements using the construction material. On the other hand, when asked about the use of timber in projects, only $6.88 \%$ of the surveyees utilized the material very often in their building projects, whereas $60.85 \%$ never or barely used timber in any construction site.

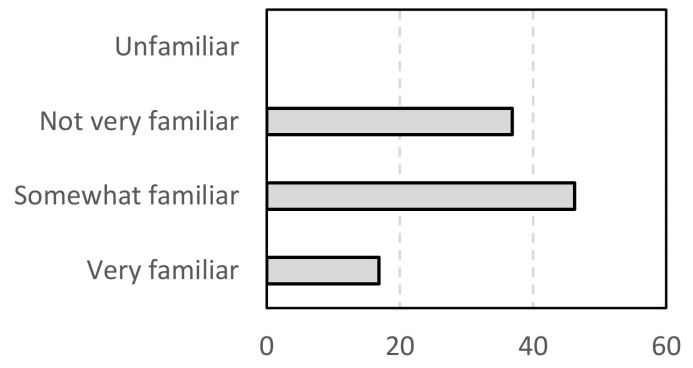

(a)

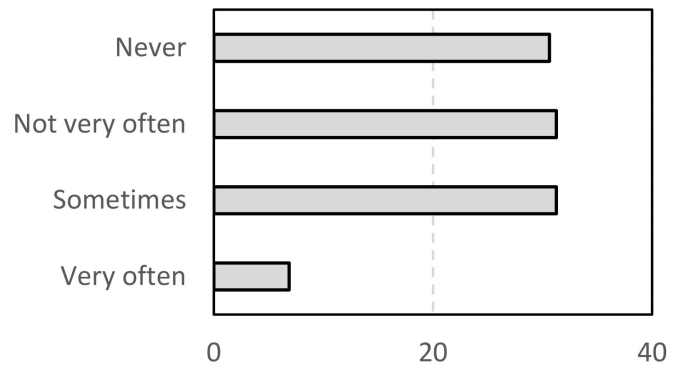

(b)

Figure 4. KRI AEC industry familiarity with timber construction (a) and structural use of timber in the KRI (b).

It is important to remark that only $37.39 \%$ of respondents used (at least once) timber as the main construction material for the skeletal structure of a building (Figure $4 \mathrm{~b}$ ). This result shows a low importance of structural timber in the KRI, as presented by Samih (2017) [36]. Notice that from the structural timber used in the region, $72.66 \%$ was imported, highlighting the problem of the lack of timber in the KRI. Even though this is regarded as a big issue, as seen in Table 1, the results shown in Figure 5 present a determination to use timber in future designs in order to fulfil the international sustainability objectives. In that sense, $55.56 \%$ of respondents were likely to use this material in the future, whereas $6.53 \%$ preferred not to use timber in their designs/constructions. Therefore, there is an interest in using timber in the KRI that could increase sustainability in the sector if the main barriers of using this material were minimized. Reducing the current drawbacks of timber would even increase the numbers of respondents willing to design with the material, since the surveyees from the uncertain group comprised up to $32.03 \%$.

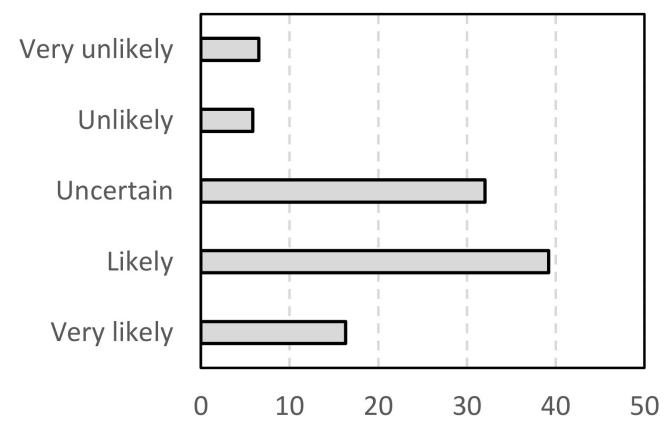

Figure 5. Likeliness of using timber in future designs/constructions (units: \%).

To understand better the low use of timber in the KRI, the survey presented a list of seven possible barriers that prevented the further use of it: volume of wood required (VWR), availability in the market (AM), structural performance (SP), cost of material (CM), fire resistance (FR), knowledge and expertise (KE), and compatibility with building codes and regulations (CBCR). Figure 6 presents the results obtained for each one of these barriers in $\%$. Notice that these barriers are not pretended to be related only to solid timber but also to engineered wood products. 


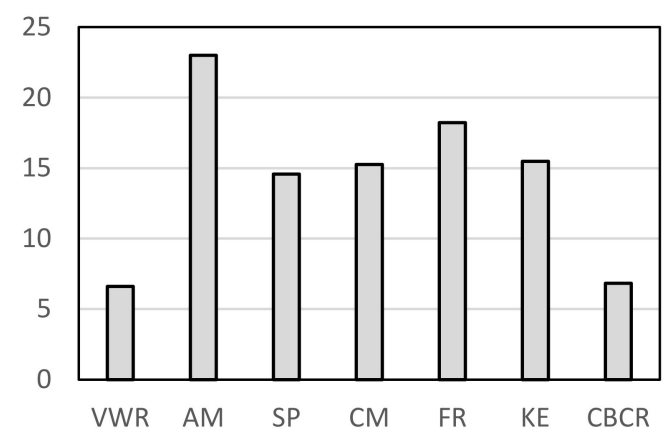

Figure 6. Barriers to increase usage of timber.

As mentioned in former sections, the most important barriers were the availability in the market $(23.01 \%)$. Other barriers with high impact related to the use of timber as a construction material in the KRI were fire resistance $(18.22 \%)$ and the knowledge and expertise of the staff who needs to design and construct with timber (15.49\%). Finally, it is worth mentioning that $14.58 \%$ of respondents chose structural performance, which could be related to a lack of knowledge and expertise. Notice that these barriers are common in semi-arid regions but not in the rest of the world [14,33-35].

\section{Discussion}

Based on the results obtained, different proposals are presented that aim to bust the utilization of timber and timber products in the KRI. These proposals are presented to give information to the AEC industry and to provide data to researchers in the region to reconsider research lines and therefore be more interested in considering timber in construction to enhance the sustainability of the sector. Proposals are made that take into account the main barriers that the AEC industry communicated through the survey. Then, availability in the market, fire resistance, and technicality (knowledge and expertise and structural performance) are regarded.

\subsection{Availability in the Market}

Forests in Iraq are currently facing several threats, such as wind extraction, fire risks, serious forest pests or diseases, and damage by livestock and wild animals. Climate change is associated with reductions in annual rainfall rates and therefore increases in drought, which threatens forests and increases fire risk [37]. These drawbacks compromise the use of timber in construction, making the availability in the market one of the main barriers to increasing the use of this material in the KRI.

Wood is one of the traditional building materials used by the KRI, but it is currently used in a limited range. There is not a large amount of high-quality local wood in the KRI that can meet architectural or decorative requirements. Therefore, most types of wood are imported. The main reason for people's reluctance to using wood in constructing buildings is because wood is an expensive material compared to concrete, which is abundant. Furthermore, the level of wood manufacturing and product technology in the KRI is low [38].

Agroforestry and sustainable forestry practices can remedy this significant barrier. Agroforestry refers to a dynamic, ecologically based natural resource management system that, through the integration of trees in farms, diversifies and sustains production for increased social, economic, and environmental benefits for land use at all levels [39]. Farmers plant trees not only for timber but also for a variety of other products and services, such as medicines and resins. Therefore, timber is a secondary product, harvested only after the tree has served its primary production or service role. In addition, by maintaining a balance between disturbance and regeneration, mimicking natural patterns, and considering purely an ecological perspective, timber can be produced. To that aim, sustainable forestry practices need to be stablished and implemented [40-42]. Notice that monitoring forest dynamics to measure vegetation changes caused by humans is vital to attaining sustainable 
development, because striking a balance between conservation and the sustainable use of forests is a global challenge [43].

Wood supply may be available indefinitely if it is sourced from sustainably managed forests [44]. Scotland, for example, is growing more wood than it harvests because of sustainable forestry practices [45]. Even though Scotland is a country with no semi-arid regions, other countries such as Australia, South Africa, and Morocco, which present big semi-arid regions, apply sustainable forestry practices to make better use of their forests with great results [9].

To apply these practices, the selection of tree species is fundamental. Traditionally, farmers grow trees using local seed sources to provide products and services that support their needs and farming systems. These tree species used are not necessarily those sought by the timber market. In that sense, eucalyptus trees are used in many countries with semi-arid regions to produce timber $[9,46]$. Studies recommended eucalyptus trees to be grown in the KRI as a source for the lumber industry [47,48], since after studying the wood density and mechanical properties of eucalyptus, the feasibility of using the material for construction was demonstrated.

Finally, it is important to remark that agroforestry and sustainable forestry generate more advantages than producing timber. These procedures preserve the aesthetics of nature and the environment, leading to a possible promotion of tourism, which may contribute to the national economy. Besides, studies have demonstrated that forestry practices can protect and regenerate degraded soil [49]. Finally, these activities provide job opportunities for local people [37].

\subsection{Fire Resistance}

Regarding fire attacks, timber is a combustible material. When exposed to the heat of fire, it goes through a process of thermal breakdown into combustible gases, called pyrolysis, releasing atoms and energy. This burning process in timber is slow, predictable and measurable due to the layer of charcoal formed on its surface [50]. In addition, the reduction in the section of effective elements is the responsible for the loss of structural performance and, in some cases, the structural collapse This fact makes the material unappealing for the AEC industry.

To minimize this, timber construction elements need to be protected against fire. The classical approach to give this protection is given through coatings and/or the impregnation of chemical additions called fire retardants, which aim to minimize the efficiency of the pyrolysis chemical processes [51]. Many researchers have studied the use of fire retardants for timber. Investigations show greater efficiency of impregnation against coating systems and highlighted the benefits of using halogen-based and boron-based retardants, which are the most common additives in the global market, in reducing the impact on the rate of fire growth. In that sense, researchers have presented the risk of using these products due to the health issues they cause and demonstrated that these drawbacks can be minimized with phosphorus-based and phosphorous-nitrogen-based retardants, which are less effectives but are considered a low-toxicity product for humans and the environment [51].

Currently, more innovative approaches are being studied, including nanocomposite fire-retardant compounds and intumescent fire-retardant systems. The first uses nanomaterials to improve the characteristics of timber. Studies performed in 2015 [52] produced wood samples coated with vermiculite and various vermiculite-sodium silicate composites, which exhibited a solid foamy layer effective at delaying ignition and decreasing both the heat-released rate and the total heat released. On the other hand, cellulose nanofiber/clay nanocomposites, with a unique brick-and-mortar structure, were proposed by Carosio et al. [53] as a sustainable and efficient fire protection coating for wood. With the same aim, intumescent fire-retardant systems swell and increase their volume by 50 to 200 times, forming a thick porous charred layer as a protective barrier and providing resistance to both heat and mass transfer. In that sense, a new class of intumescent coatings with potential application to wood and wood-based products is based on clay-organic hy- 
brid systems [54]. A study conducted by Kim et al. [54] used polyethylene vinyl acetic acid combined with ammonium phosphate monobasic, mono-pentaerythritol, melamine, and a cationic nano-clay (pristine clay) to produce the retardant system. The study presented excellent results for future applications in timber construction.

\subsection{Technicality}

\subsubsection{Knowledge and Expertise}

A code is a document covering a system of laws that apply to construction. It is a document containing standardized requirements that specify the minimum acceptable limit of safety for buildings and structures. These codes are based on the experience of engineers, experimental work, and the specific conditions of a location. There is no national building code in Iraq, including the KRI. Therefore, it is recommended that engineers and designers use American and European codes and standards. In that sense, the Eurocode (Eurocode 5 for timber structures [55]) covers all design and construction requirements for different types of modern buildings and materials as well as common materials, and is accepted for the majority of the AEC industry in the KRI [56].

Most countries have their own national building codes. They are usually adopted and developed by governmental building institutes dependent on the international codes. The importance of national codes resides in defining three main criteria that may differ from country to country: geotechnical requirements, loading conditions, and materials. In that sense, the lack of a national code for timber construction in the KRI demonstrates the absence of expertise and knowledge on this technology. Therefore, as studies have demonstrated, there is a need to develop building codes for Iraq, and especially timber construction codes and standards that comply with the singular requirements of the country.

\subsubsection{Structural Performance}

On the other hand, the structural performance of timber is not that shown by conventional construction materials. Firstly, compressive strength, which is a fundamental structural design parameter shown by timber, is between 30 and $70 \mathrm{MPa}$, whereas values of $100 \mathrm{MPa}$ and $250 \mathrm{MPa}$ can be achieved with concretes and steels. Besides, timber stiffness is lower, so higher deformations are experienced in timber structures with given external forces. These limit the use of timber in highly demanding structural performance buildings such as high-rise buildings. Hence, to minimize these technical disadvantages, new developments in timber construction took place, generating engineered wood products (EWP) or advanced timber composites. These include a range of derivative wood products manufactured by binding or fixing the strands, particles, fibers, or veneers or boards of wood, together with adhesives or other methods of fixation to form composite material [57]. Cross-laminated timber (CLT), glulam, laminated veneer lumber (LVL), and plywood are the most used EWPs to enhance the structural performance of plain solid timber (Figure 7).

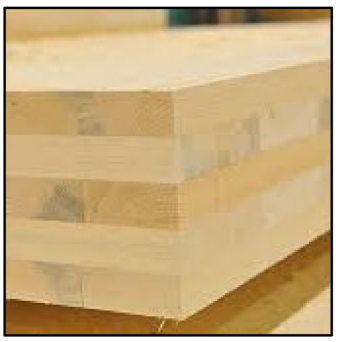

(a)

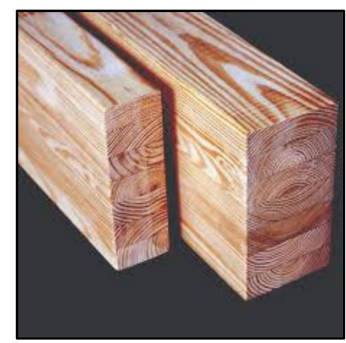

(b)

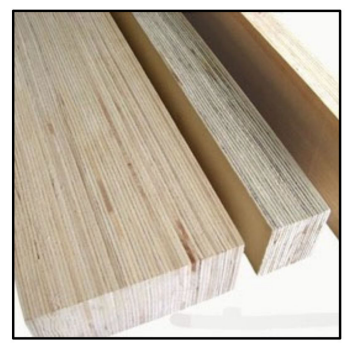

(c)

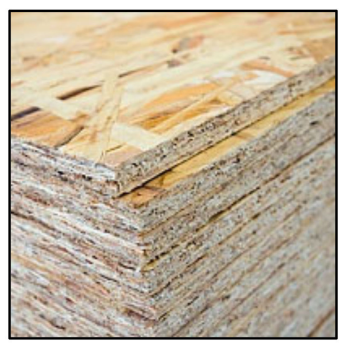

(d)

Figure 7. Cross-laminated timber (CLT) (a), glulam (b), laminated veneer lumber (LVL) (c), and plywood (d).

Due to the utilization of EWPs, the construction industry has started regarding timber as a solution around the globe even to construct important structures such as high-rise buildings $[14,58]$. Examples of that are the current buildings named Lighthouse Joensuu 
and Mjøstårnet, in Finland and Norway, respectively (Figure 8a,b, respectively). The first is a $50 \mathrm{~m}$ high-rise building that accommodates 117 apartments. During its construction, the European Commission concluded that the goal of net-zero carbon dioxide emissions during construction could be reached almost fully if wood were chosen as the construction material. The second is the highest timber building built today. It reaches about $85 \mathrm{~m}$ height and includes a hotel, restaurants, offices, and apartments. To construct the tower, builders concluded that timber was strong enough to replace carbon-intensive concrete or steel and required less energy to produce. Other examples that demonstrate the social acceptance of timber are the futuristic skyscraper designs in Tokyo (Japan) and Lagos (Nigeria) (Figure 8c,d respectively): the W350 Project (Nikken Sekkei, $350 \mathrm{~m}$ height) and the Lagos Wooden Tower (HKA I Hermann Kamte \& Associates, $87 \mathrm{~m}$ height), respectively. However, not all technical problems of using timber have been solved and the design of these current and future buildings was carried out to a maximum of $80 \%$, since the designs needed concrete and/or steel structural cores to sustain the main loads of the building [58].

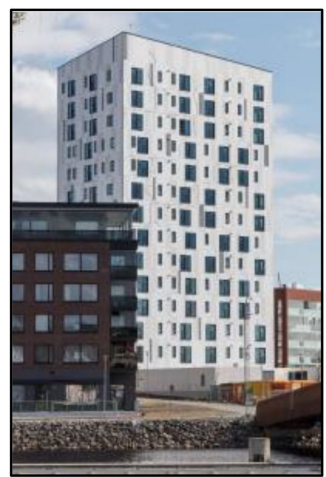

(a)

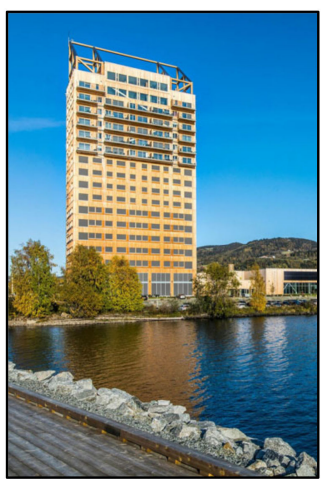

(b)

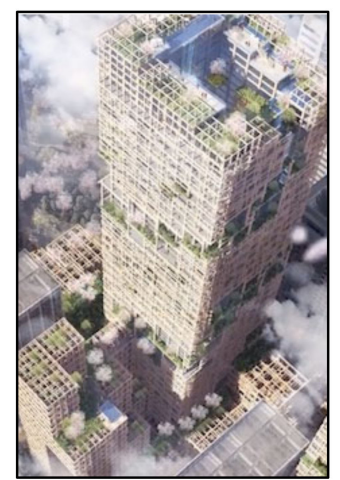

(c)

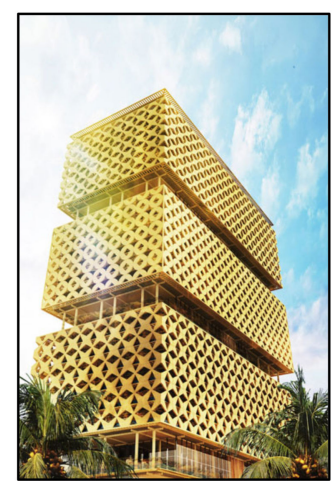

(d)

Figure 8. Timber high-rise buildings: Lighthouse Joensuu (a), Mjøstårnet (b), W350 Project (c), and Lagos Wooden Tower (d).

After being ask whether the respondents in our study used wood products, including solid timber and EWPs (Figure 7), 21.25\% of respondents selected the option of "never used wood-based products". This shows how low = timber construction is in the KRI. A total of $23.75 \%$ of respondents used solid timber in their projects, whereas regarding EWPs, $45.63 \%$ of participants used plywood. Notice that this EWP is mainly used for non-structural applications such as light partitions, external walls, and the production of formwork $[59,60]$. Regarding the EWPs normally used for structural elements in buildings, only $5.63 \%, 2.50 \%$, and $1.25 \%$ of surveyees used glulam, LVL, and CLT, respectively. These results highlight the low importance of timber in KRI constructions and therefore the possibility of using them to increase the number of timber buildings. Notice that this is in accordance with Espinoza et al. [61] and Mallo and Espinoza [62]. These studies on the use of EWPs in United States showed that participants thought that, in general, the level of awareness about EWPs among developers, construction managers, engineers, architects, and construction managers is low.

However, even though EWPs are increasingly being used as construction and building materials in many countries, the current structural limitations and the predominant use of petroleum-based adhesives, which are the key element to produce EWPs, contribute to the release of toxic gases [63], and the global AEC industry does not regard timber as the solution. That is the reason why investigators are looking for other options to improve timber and make it an actual competitor to conventional construction materials. In that regard, researchers are working on two different ways: producing new composites using timber and other materials and strengthening timber itself.

Timber can be utilized effectively in conjunction with steel and concrete to produce more sustainable composite structures. In that sense, researchers have demonstrated the benefits of these composites. For instance, Mohammed and Mohammed [64] studied 
concrete-timber composites to build flat roofs, revealing that composites present better structural behavior than timber elements and are more sustainable that concrete elements. Ceccotti et al. [65] reported the results of a collapse test performed on a $6 \mathrm{~m}$-span timberconcrete composite beam, demonstrating that the composite increased the resilience of the structural elements. Mirdad et al. [66] discovered that increasing timber thickness for a timber-concrete composite floor system led to more strength and stiffness to weight ratios, which may have helped reduce the size of lateral load resisting systems and foundations, and therefore reducing the overall structure's embodied carbon.

On the other hand, researchers have showed the benefits of timber-steel composites. Navaratnam et al. [67] presented the feasibility of developing cross-laminated timber (CLT) and cold-formed steel (CFS) composite beams for a floor system. The CLTCFS composite beams increased the ultimate bending performance by $20 \%$, according to the findings. Wang et al. [68] demonstrated that the stiffness, strength, and ductility of timber-steel hybrid beams with and without splice improved significantly. According to Chiniforush et al. [69], using steel-timber composite (STC) floor and shear wall systems while designing a building with a steel framework resulted in a $107.5 \%$ reduction in embodied energy at the expense of only a minor increase in operating energy. To sum up, using timber-concrete or steel-timber composites provide several advantages, including improved stability and structural behavior, improved thermal and sound insulation performance, reduced building self-weight, and lower $\mathrm{CO}_{2}$ emissions [70-72].

Finally, a methodology called thermo-hydromechanical (THM) densification is a technique for modifying wood by compression in the transverse direction of the wood, which is the weaker one due to the nature of the material. Wood is a porous material that consists mainly of the structural polymers' cellulose, hemicelluloses, and lignin, and the behavior of those components can be altered by heat and moisture. Therefore, heat, steam, and mechanical compression can be used to densify and fix the wood material. The principle of THM processing has been thoroughly described by Navi and Sandberg [73]. Studies demonstrate that densified wood presents excellent mechanical properties. A clear example of this is the bulletproof wood developed at the University of Maryland based on densified wood [74]. However, no application of densified wood as a construction material has been published yet mainly since the production of densified wood as a new technique is linked to a high cost.

In that context, research could be proposed to produce new engineered wood products based on the innovative techniques described. In that sense, to combine the goodness of each application and optimize (economically and technically) future prototypes, the functionally graded method (FGM) concept could be used. Functionally graded materials are more competent composite materials that present changeable properties throughout the volume to obtain a desired performance [75]. This has been applied to aeronautical and computer science industries and it is being applied now in the construction industry to improve concrete elements [76]. Therefore, researchers could produce new prototypes of enhanced engineered wood products to minimize the current disadvantages of timber versus conventional construction materials.

\section{Conclusions}

The results presented in this study helps the reader understand how timber is used in the KRI and clearly demonstrate that timber could be further used in the construction industry in semi-arid regions following the same patterns as the KRI due to several advantages. It should be noted, however, there are many obstacles resulting from low availability in the national market, including timber technology development and the lack of relevant legislation and design and construction codes. To improve the situation, it is suggested that more research effort from the main stakeholders in the construction industry, such as government and universities, should be made to address different aspects of timber's further utilization. 
Author Contributions: Conceptualization, I.G. and M.Y.A.; methodology, I.G. and M.Y.A.; validation, I.G. and M.Y.A.; formal analysis, I.G.; investigation, M.Y.A.; resources, M.Y.A.; writing-original draft preparation, I.G.; writing-review and editing, I.G., M.Y.A. and H.R. All authors have read and agreed to the published version of the manuscript.

Funding: This research received no external funding.

Institutional Review Board Statement: Not applicable.

Informed Consent Statement: Not applicable.

Data Availability Statement: Data available on request due to restrictions (privacy). The data presented in this study are available on request from the corresponding author.

Acknowledgments: The authors would like to thank the School of Architecture, Planning \& Design $(\mathrm{SAP}+\mathrm{D})$ at Mohammed VI Polytechnic University (UM6P) for the financial support received for the publication of the article.

Conflicts of Interest: The authors declare no conflict of interest.

\section{References}

1. United Nations Environment Programme. 2020 Global Status Report for Buildings and Construction: Towards a Zero-Emission, Efficient and Resilient Buildings and Construction Sector; UN Environment and the International Energy Agency: Nairobi, Kenya, 2020.

2. Zhang, Z.; Provis, J.; Reid, A.; Wang, H. Geopolymer foam concrete: An emerging material for sustainable construction. Constr. Build. Mater. 2014, 56, 113-127. [CrossRef]

3. U.S. Geological Survey. Mineral Commodity Summaries_Tracking Report. Available online: https://www.iea.org/reports/cement (accessed on 20 July 2020).

4. Lynch, H. Environment or Development: Can Kurdish Cement Boom Balance Both. Available online: https://www.rudaw.net/ english/business/15022020 (accessed on 20 July 2020).

5. Koehn, E.; Ahmmed, M. Quality of building construction materials (cement) in developing countries. J. Arch. Eng. 2001, 7, 44-50. [CrossRef]

6. Ürge-Vorsatz, D.; Cabeza, L.F.; Serrano, S.; Barreneche, C.; Petrichenko, K. Heating and cooling energy trends in buildings. Renew. Sustain. Energy Rev. 2015, 41, 85. [CrossRef]

7. Das, B.B.; Neithalath, N. Sustainable construction and building materials. In Select Proceedings of ICSCBM 2018; Springer: Singapore, 2018. [CrossRef]

8. Ramage, M.H.; Burridge, H.; Busse-Wicher, M.; Fereday, G.; Reynolds, T.; Shah, D.U.; Wu, G.; Yu, L.; Fleming, P.; Densley-Tingley, D.; et al. The wood from the trees: The use of timber in construction. Renew. Sustain. Energy Rev. 2017, 68, 333-359. [CrossRef]

9. Genin, D.; Simenel, R. Endogenous berber forest management and the functional shaping of rural forests in southern Morocco: Implications for shared forest management options. Hum. Ecol. 2011, 39, 257-269. [CrossRef]

10. Lippke, B.; Wilson, J.; Perez-Garcia, J.; Boyer, J.; Meil, J. CORRIM: Life-cycle environmental performance of renewable building materials. For. Prod. J. 2004, 54, 8-19.

11. Dennehy, K. Using more wood for construction can slash global alliance on fossil fuels. In Yale News; Office of Public Affairs \& Communications, Yale University: New Haven, CT, USA, 2014.

12. Yue, M.; Li, W.; Cheng, X.; Chen, Y.; Xu, L.; Shi, Y. Study on energy conservation and carbon emission reduction design of timber structure building. J. Eng. 2019, 2019, 5455-5466. [CrossRef]

13. Roberts, D. The Hottest New Thing in Sustainable Building Is, uh, Wood. Available online: https://www.vox.com/energy-andenvironment/2020/1/15/21058051/climate-change-building-materials-mass-timber-cross-laminated-clt (accessed on 20 July 2020).

14. Gold, S.; Rubik, F. Consumer attitudes towards timber as a construction material and towards timber frame houses-Selected findings of a representative survey among the German population. J. Clean. Prod. 2009, 17, 303-309. [CrossRef]

15. Xia, B.; O'Neill, T.; Zuo, J.; Skitmore, M.; Chen, Q.; Skitmore, R. Perceived obstacles to multi-storey timber-frame construction: An Australian study. Arch. Sci. Rev. 2014, 57, 169-176. [CrossRef]

16. Caniato, M.; Bettarello, F.; Ferluga, A.; Marsich, L.; Schmid, C.; Fausti, P. Thermal and acoustic performance expectations on timber buildings. Build. Acoust. 2017, 24, 219-237. [CrossRef]

17. Petruch, M.; Walcher, D. Timber for future? Attitudes towards timber construction by young millennials in Austria-Marketing implications from a representative study. J. Clean. Prod. 2021, 294, 126324. [CrossRef]

18. Mohammed, A.O. Evaluation of Multi-Storey Housing Projects in the Context of Sustainability/The City of Duhok. Master's Thesis, University of Duhok, Duhok, Iraq, 2013.

19. Wirya, S.; Salah, M.; Kuzović, D. LEED rating system barriers in the construction sector in Northern Iraq. Industrija 2017, 45, 167-186. [CrossRef] 
20. Li, J.; Rismanchi, B.; Ngo, T. Feasibility study to estimate the environmental benefits of utilising timber to construct high-rise buildings in Australia. Build. Environ. 2018, 147, 108-120. [CrossRef]

21. Tahir, B.; Wang, X.; Zhong, Y.; Mezori, H.; Liu, Y.; Liao, W. Bioethanol production from leaves of Quercus infectoria in Kurdistan region. Res. Sq. 2020. [CrossRef]

22. Eklund, L.; Abdi, A.; Shahpurwala, A.; Dinc, P. On the geopolitics of fire, conflict and land in the Kurdistan region of Iraq. Remote Sens. 2021, 13, 1575. [CrossRef]

23. Abdullah, R. 2.2 Million Acres of Forest Lost to Fire, Deforestation, Budget Cuts: KRG. Available online: https: / /www.rudaw. net/english/kurdistan/171020182 (accessed on 20 July 2020).

24. Khwarahm, N.R. Mapping current and potential future distributions of the oak tree (Quercus aegilops) in the Kurdistan region, Iraq. Ecol. Process. 2020, 9, 56. [CrossRef]

25. Aree, A.A.; Suliman, H.H.; Saeed, H.S.; Dawod, N.A. Some of phenotypic, physical and anatomical wood properties of valonia oak trees in Kurdistan Iraq. Iraqi J. Agric. Sci. 2021, 52, 589-600. [CrossRef]

26. United Nations Development Programme. Drought_Impact Assessment, Recovery and Mitigation Framework and Regional Project Design in Kurdistan Region (KR); United Nations Development Programme: New York, NY, USA, 2010.

27. Mosa, W.L. Forest Cover Change and Migration in Iraqi Kurdistan: A Case Study from Zawita Sub-District; Michigan State University: East Lansing, MI, USA, 2016.

28. International Organization for Migration. Demography Survey: Kurdistan Region of Iraq; UN Migration: Geneva, Switzerland, 2018.

29. Khoshnaw, R. Sustainable construction in Kurdish vernacular architecture. Period. Polytech. Arch. 2019, 50, 178-185. [CrossRef]

30. Karol, S.; Jianli, H.; Isaac, G.; Weiqi, X.; Subo, W.; Zitong, C. Feasibility study on further utilization of timber in China. IOP Conf. Series Mater. Sci. Eng. 2018, 383, 012029. [CrossRef]

31. Gibbons, M.J.; Nikafshar, S.; Saravi, T.; Ohno, K.; Chandra, S.; Nejad, M. Analysis of a wide range of commercial exterior wood coatings. Coatings 2020, 10, 1013. [CrossRef]

32. Preston, V. Questionnaire survey. Int. Encycl. Hum. Geogr. 2009, 46-52. [CrossRef]

33. Evison, D.C. Mass timber construction in Australia and New Zealand-Status, and economic and environmental influences on adoption. Wood Fiber Sci. 2018, 50, 128-138. [CrossRef]

34. Adeli, K.; Yachkaschi, A.; Limaei, S.M.; Fallah, A. A Study of the condition of timber production in Iran and the expected production rate in the next decade. J. Sustain. Dev. 2011, 5, 144. [CrossRef]

35. Crafford, P.; Wessels, C.B. South African log resource availability and potential environment impact of timber construction. S. Afr. J. Sci. 2020, 116, 7-8. [CrossRef]

36. Kalwry, H.S.K. An Investigation of Building Construction and Materials Issues in Northern Iraq for Residential Projects. Master's Thesis, Eastern Mediterranean University (EMU)-Doğu Akdeniz Üniversitesi (DAÜ), Famagusta, Turkey, 2017.

37. Rida, N.M.; Hussein, A.A.; Ahmed, D.A.; Mousa, R.M.; Abid, M.F.; Hassan, R.A.; Salman, A.N. Sixth National Report of Iraq to the Convention on Biological Diversity; Ministry of Health and Environment, and Convention on Biological Diversity: Baghdad, Iraq, 2018.

38. Shatz Howard, J.; Constant, L.; Luoto, J.E.; Smith, A.; Abramzon, S. An Assessment of the Present and Future Labor Market in the Kurdistan Region-Iraq, Implications for Policies to Increase Private-Sector Employment; RAND Corporation: Santa Monica, CA, USA, 2014.

39. Coe, R. Farmer-designed agroforestry trials: Farmers' experiences in western Kenya. In Trees and Farmers: Assessing the Adoption Potential of Agroforestry Practices in Africa; Franzel, S., Scherr, S., Eds.; World Agroforestry Centre (ICRAF): Nairobi, Kenya, 1998.

40. Larocque, G.R. Ecological Forest Management Handbook; CRC Press, Taylor \& Francis: Boca Raton, FL, USA, 2016.

41. Oliver, C.D. Sustainable forestry: What is it? How do we achieve it? J. For. 2003, 101, 8-14.

42. Flueck, W.T. Evolution of forest systems: The role of biogeochemical cycles in determining sustainable forestry practices. Ecol. Soc. 2009, 14, r4. [CrossRef]

43. Eulewi, H.K.; Hasan, A. Monitoring of the temporal changes in the forests of northern Iraq through the directed classification and the index of natural vegetative difference. Plant Arch. 2020, 20, 5745-5750.

44. Adedeji, A.A.; Jimoh, A.A.; Aina, S.T. Timber as a Sustainable Construction Material; Its Impact on Climate Change and Innovative Development of the African Continent; Africa Unity for Renaissance Conference: Pretoria, South Africa, 2017.

45. Wilson, P.L. Designing with timber, Adleaderin Association with ARCA. In Proceedings of the Conference on Scottish Hardwoods, New Lanark, UK, 14 March 2000. Organised by the Scottish Hardwood Timber Market Development Group.

46. du Toit, B.; Malherbe, G.F.; Kunneke, A.; Seifert, T.; Wessels, B. Survival and long-term growth of eucalypts on semi-arid sites in a Mediterranean climate, South Africa. South. For. 2017, 79, 1-15. [CrossRef]

47. Taha, M.A.Y.; Abd Ali, B.A. Estimating waste wood through conversion of whole stem into lumber of Eucalyptus camaldulensis growing in Askikalak Kurdistan region of Iraq. In Proceedings of the 2nd Scientific Agricultural Conference, Kurdistan Region of Iraq, Iraq, 26-27 April 2016; p. 273.

48. Taha, M.A.Y. Some technological properties of sawn board Eucalyptus Camaldulensis Denh. grown in Askikalak. Sci. J. Univ. Zakho 2015, 3, 107-112. [CrossRef]

49. Foroughbakhch, R.; Carrillo-Parra, A.; Hernandez-Pinero, J.L.; Guzman, M.A. Growth and yield of an eucalyptus subtropical plantation in a Northeastern Mexico degraded land soil. Madera y Bosques 2017, 23, 71-85. [CrossRef] 
50. Lowden, L.A.; Hull, T.R. Flammability behaviour of wood and a review of the methods for its reduction. Fire Sci. Rev. $2013,2,4$. [CrossRef]

51. Popescu, C.; Pfriem, A. Treatments and modification to improve the reaction to fire of wood and wood based productsAn overview. Fire Mater. 2019, 44, 100-111. [CrossRef]

52. Kumar, S.P.; Takamori, S.; Araki, H.; Kuroda, S. Flame retardancy of clay-sodium silicate composite coatings on wood for construction purposes. RSC Adv. 2015, 5, 34109-34116. [CrossRef]

53. Carosio, F.; Cuttica, F.; Medina, L.; Berglund, L.A. Clay nanopaper as ultifunctional brick and mortar fire protection coatingWood case study. Maternite 2016, 93, 357-363. [CrossRef]

54. Kim, H.; Park, J.W.; Lee, J.H.; Jang, S.W.; Kim, H.J.; Choi, Y.; Choy, J.H.; Yang, J.H. Clay-organic intumescent hybrid system for the synergetic flammability of polymer nanocomposites. J. Therm. Anal. Calorim. 2018, 132, 2009-2014. [CrossRef]

55. European Committee for Standardization. Eurocode 5: Design of Timber Structure; BSI: Brussels, Belgium, 1994.

56. Al-Taie, E.; Al-Ansari, N.; Knutsson, S. The need to develop a building code for Iraq. Engineering 2014, 6, 610-632. [CrossRef]

57. Grebner, A.L.; Bettinger, P.; Siry, J.P. Introduction to Forestry and Natural Resources, 2nd ed.; Academic Press: Cambridge, MA, USA, 2021; ISBN 978-0-12-819002-9.

58. Foster, R.M.; Ramage, H. Tall timber. In Nonconventional and Vernacular Construction Materials, 2nd ed.; Woodhead Publishing, Elsevier: Amsterdam, The Netherlands, 2020; pp. 467-490.

59. Yue, K.; Liang, B.; Shao, Y.; Xie, C.; Hu, W.; Zhao, M.; Chen, Z.; Lu, W. Lateral behavior of wood frame shear walls sheathed with densified plywood under monotonic loading. Thin Walled Struct. 2021, 166, 108082. [CrossRef]

60. Sankar, A.; Sajan, S. Manufacturing of high strength plywood composites reinforced with copper fibers. Mater. Today Proc. 2021, 47, 5255-5259. [CrossRef]

61. Mallo, M.F.L.; Espinoza, O. Awareness, perceptions and willingness to adopt Cross-Laminated Timber by the architecture community in the United States. J. Clean. Prod. 2015, 94, 198-210. [CrossRef]

62. Agyekum, K.; Kissi, E.; Danku, J.C. Professionals' views of vernacular building materials and techniques for green building delivery in Ghana. Sci. Afr. 2020, 8, e00424. [CrossRef]

63. Xian-Qing, X.; Ying-Ying, Y.; Yi-Ting, N.; Liang-Ting, Z. Development of a cornstarch adhesive for laminated veneer lumber bonding for use in engineered wood flooring. Int. J. Adhes. 2019, 98, 102534. [CrossRef]

64. Mohammed, A.A.; Mohammed, O.K. Composite concrete-Unregularized timber section for flat roof construction. Structures 2020, 27, 1324-1334. [CrossRef]

65. Ceccotti, A.; Fragiacomo, M.; Giordano, S. Long-term and collapse tests on a timber-concrete composite beam with glued-in connection. Mater. Struct. 2006, 40, 15-25. [CrossRef]

66. Mirdad, A.H.; Daneshvar, H.; Joyce, T.; Chui, Y.H. Sustainability design considerations for timber-concrete composite floor systems. Adv. Civ. Eng. 2021, 2021, 6688076. [CrossRef]

67. Navaratnam, S.; Small, D.W.; Gatheeshgar, P.; Poologanathan, K.; Thamboo, J.; Higgins, C.; Mendis, P. Development of cross laminated timber-cold-formed steel composite beam for floor system to sustainable modular building construction. Structures 2021, 32, 681-690. [CrossRef]

68. Wang, T.; Wang, Y.; Crocetti, R.; Franco, L.; Schweigler, M.; Wålinder, M. An innovative timber-steel hybrid beam consisting of glulam mechanically reinforced by means of steel rod: Analytical and preliminary numerical investigations. J. Build. Eng. 2021, 43, 102549. [CrossRef]

69. Chiniforush, A.A.; Akbarnezhad, A.; Valipour, H.; Xiao, J. Energy implications of using steel-timber composite (STC) elements in buildings. Energy Build. 2018, 176, 203-215. [CrossRef]

70. Perković, N.; Rajčić, V.; Barbalić, J. Analytical and numerical verification of vibration design in timber concrete composite floors. Forests 2021, 12, 707. [CrossRef]

71. Chiniforush, A.A.; Valipour, H.; Akbarnezhad, A.; Bradford, M. 08.27: Steel-timber composite (STC) beams: Numerical simulation of long-term behaviour. ce/papers 2017, 1, 2051-2059. [CrossRef]

72. Dias, A.; Skinner, J.; Crews, K.; Tannert, T. Timber-concrete-composites increasing the use of timber in construction. Eur. J. Wood Wood Prod. 2015, 74, 443-451. [CrossRef]

73. Sandberg, D.; Kutnar, A. Thermally modified timber: Recent developments in Europe and North America. Wood Fiber Sci. 2016, $48,28-39$.

74. Song, J.; Chen, C.; Zhu, S.; Zhu, M.; Dai, J.; Ray, U.; Li, Y.; Kuang, Y.; Li, Y.; Quispe, N.; et al. Processing bulk natural wood into a high-performance structural material. Nature 2018, 554, 224-228. [CrossRef]

75. Vantyghem, G.; De Corte, W.; Steeman, M.; Boel, V. Density-based topology optimization for 3D-printable building structures. Struct. Multidiscip. Optim. 2019, 60, 2391-2403. [CrossRef]

76. Chan, R.; Liu, X.; Galobardes, I. Parametric study of functionally graded concretes incorporating steel fibres and recycled aggregates. Constr. Build. Mater. 2020, 242, 118186. [CrossRef] 